\title{
ポリフェノールの機能発現に関わる分子標的
}

\section{Polyphenol Functions and Molecular Targets}

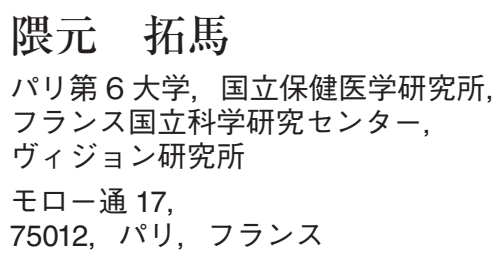

隈元 拓馬

パリ第 6 大学, 国立保健医学研究所,

フランス国立科学研究センター,

ヴィジョン研究所

モロー通 17,

75012, パリ, フランス

Takuma KUMAMOTO

Sorbonne Universités, UPMC Univ

Paris 06, INSERM U968, CNRS

UMR 7210, Institut de la Vision

17 rue Moreau,

75012, Paris, France

\section{侯 德興}

国立大学法人 鹿児島大学農学部 食料生命科学科

食品機能科学講座

食品分子機能学研究室

干 890-0065

鹿児島県鹿児島市郡元 1-21-24

De-Xing HOU

Department of Food Science and

Biotechnology, Faculty of Agriculture,

Kagoshima University

1-21-24 Korimoto, Kagoshima,

890-0065, Japan
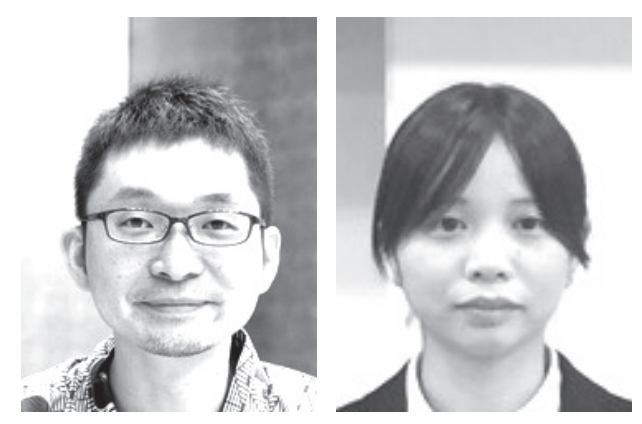

久永 絢美

国立研究開発法人

農業・食品産業技術総合研究機構

果樹茶業研究部門カンキツ研究領域

干 424-0292

静岡県静岡市清水区興津中町 485-6

Ayami HISANAGA

Division of Citrus Research

Institute of Fruit tree and Tea

Science,National Agriculture and

Food Research Organization

485-6 Okitsunaka-cho, Shimizu, Shizuoka 424-0292, Japan

論文要旨：ポリフェノールは，多くの植物性食品に存在し，様々な健康維持機能を持つ化合物である。こ れまで，ポリフェノールの機能性発現は，主にその抗酸化機能によるものだと考えられてきた。しかし，ポリ フェノールはインビトロで強い抗酸化機能を示すが, 生体内での濃度は極めて低く, 抗酸化剂としての働きが 限定的である。近年, 一部のポリフェノールまたはその代謝産物は, 生体機能を制御する細胞内信号伝達系 にある重要なプロテインキナーゼ活性を修飾していることが多く報告されている。その中の一部は，これらの プロテインキナーゼと直接結合し，そのリン酸化状態に影響し，下流の細胞信号伝達経路および遺伝子発現 を制御することで多彩な機能発現に寄与している。本総説は, ポリフェノールの機能発現における標的分子同 定のアプローチ及び最近の進展について，我々の研究グループの結果を踏まえながらまとめたものである。

Abstract: Polyphenols are abundant phytochemicals in many plant diet, and reveal many benefits to human health, of which, the antioxidant activities have been considered as a major role. Although polyphenols show higher antioxidant activities in vitro, their bioavailability are very low. Thus, the antioxidant activities in vivo are limited. Recent studies revealed that some of polyphenols or their metabolites could modulate some protein kinases locating in the cellular signaling cascades, and could directly bind to the protein kinases and modulate their activations. These modulations by polyphenols finally regulate signaling transductions and the expressions of many downstream genes. In this review, we summarize the recent results on the molecular targets of polyphenols based on the interactions of polyphenols and the target proteins.

Key words: polyphenol functions, molecular targets, protein kinases, interactions 


\section{1 はじめに}

ポリフェノールは, 多くの植物性食品に存在し, がん や心血管疾患, 神経変性疾患等の予防効果をはじめ, 様々 な健康維持機能が報告されている ${ }^{1,2)}$ 。ポリフェノール の機能性発現は, これまでそれ自身が持つ化学構造性質 により，直接的な抗酸化能力を，または生体物異物とし て細胞内解毒・レッドクス系を活性化することで間接的 な抗酸化機能を発揮するものだと考えられてきた ${ }^{3)} 。 し$ かし，このような抗酸化機能だけでは，ポリフェノール の多彩な機能性発現を完全に説明することができない。 例えば，ポリフェノールの生体吸収率は一般栄養素より 顕著に低く，それ自身またはその代謝産物の血液や組織 での濃度がナノモルレベルで極めて低いのに対し, 生体 内の抗酸化剂であるビ夕ミン $\mathrm{C}$ やビ夕ミン $\mathrm{E}$ の濃度は, マイクロモルレベルまで達している ${ }^{4,5)}$ 。このように, ポリフェノールはインビトロで強い抗酸化機能を有する が, 生体内での濃度は極めて低く, 抗酸化刻としての直 接的な働きがビタミン $\mathrm{C}$ やビタミン $\mathrm{E}$ に比べて限定的 である。近年の研究では, 一部のポリフェノールは, 多 くの生体機能を制御する細胞内信号伝達系にある重要な プロテインキナーゼ活性を修飾していることが報告され ている ${ }^{6,7)}$ 。ポリフェノールまたはその代謝産物は, プ
ロテインキナーゼに直接結合し，そのリン酸化状態に影 響し，下流の細胞信号伝達経路および遺伝子発現を制御 することで多彩な機能を発現すると考えられるように なった。一方，ポリフェノール及びその代謝産物はプロ テインキナーゼ等のタンパク質に比べると分子量が小さ く, その直接結合の検出が技術的にも困難である。本総 説は，ポリフェノールの機能発現における標的分子同定 の最近の状況について, 我々の研究グループの結果を踏 まえながらまとめたものである。

\section{2 分子標的の解析手法}

近年, ケミカルバイオロジー手法を用いて生体高分子 を狙った分子標的薬の研究が進んでいるが，ポリフェ ノールの化学性質を勘案すると, 生体分子標的への特異 性が薬ほど強くないと考えられる。このような「程々」 の分子間結合特性を検出するのが今までの手法では困難 であった。最近では, 我々のグループを含め, 複数の手 法で多方面からポリフェノールと生体タンパク質との相 互作用を検出できるようになった。その主な手法 (Fig. 1) としては，1）ポリフェノールとタンパク質の直接的結 合の検出，2）ポリフェノールとタンパク質の結合親和 力の算出, 3）ポリフェノールとタンパク質の分子結合 モデルの作成による結合部位の推定，などがある。我々 (a) Direct binding

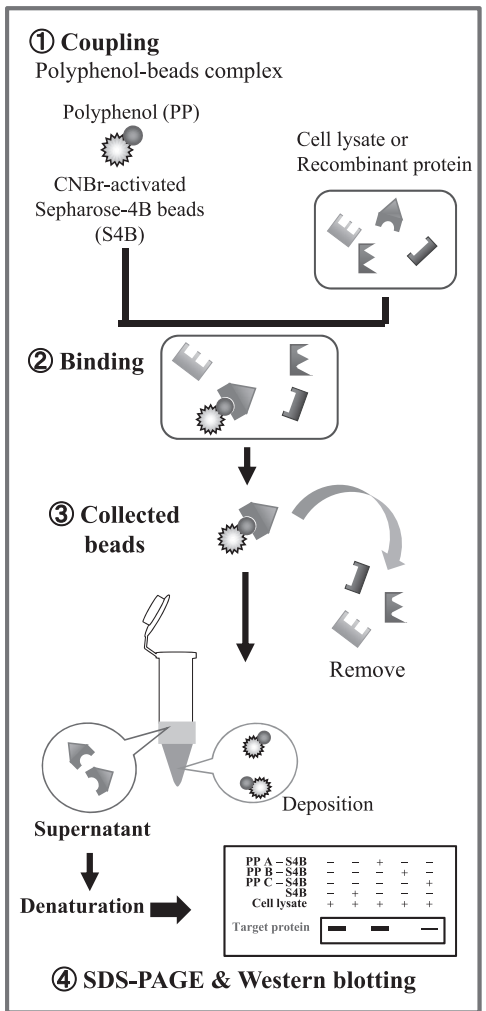

(b) Affinity analysis

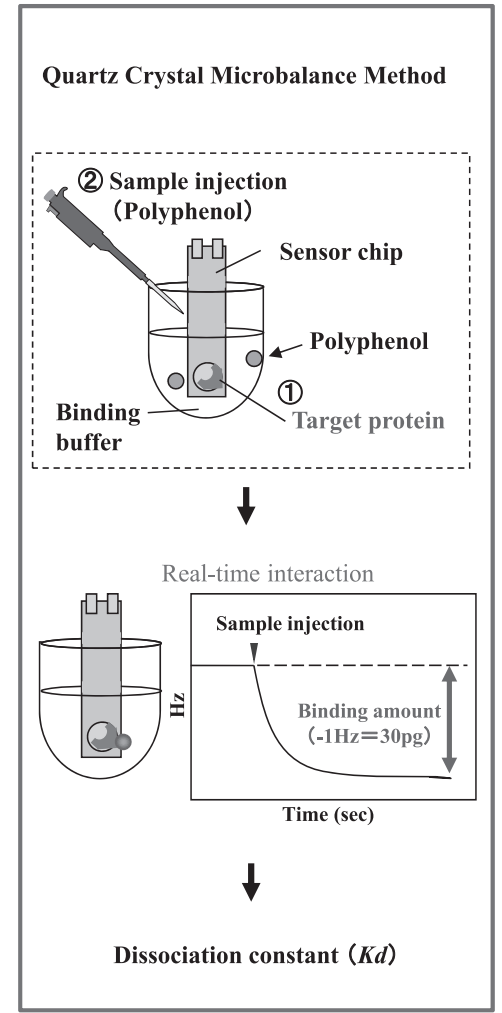

(c) Molecular modeling

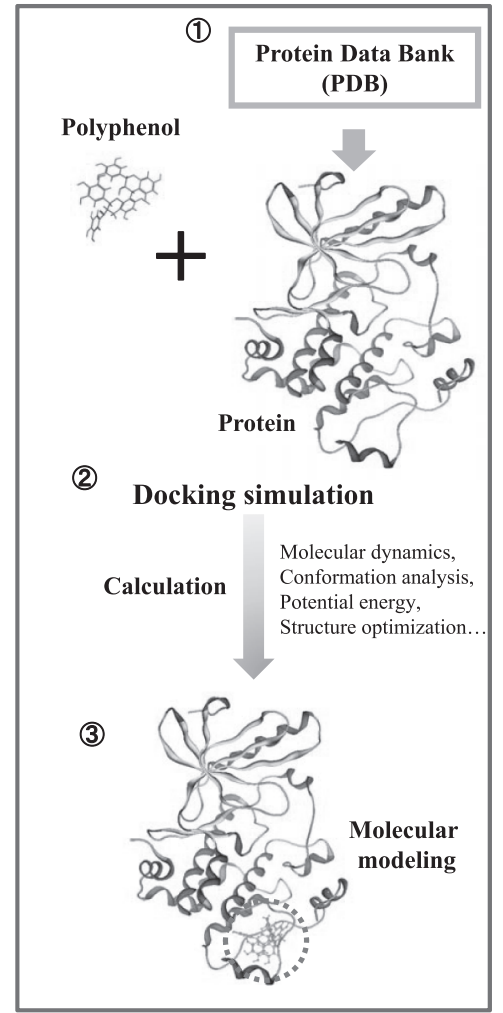

Fig. 1 ポリフェノールの標的分子の同定における解析手法（巻頭カラー写真参照） 
は，このような手法を組み合わせながら，ポリフェノー ルの生体標的分子の探索と同定を試みてきた。

\section{$2 \cdot 1$ ポリフェノールとタンパク質の直接的結合の検出}

従来タンパク質, 核酸, 多糖類等の研究でカップリン グ剂として用いられていた臭化シアン $(\mathrm{CNBr})$ 活性化

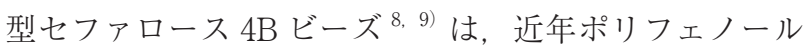
ともカップリングすることが明らかとなり，これを用い てポリフェノールとタンパク質間の相互結合を検出する プルダウンアッセイ法が確立された ${ }^{10)}$ 。プルダウンアッ セイ法では, (1)カップリングバッファー中でセファロー ス 4B ビーズとポリフェノールをカップリングし, (2)カッ

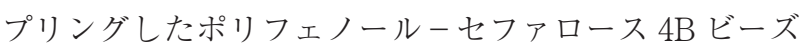
と細胞のライセートまたは精製タンパク質を反応バッ ファー中で結合させ，(3)ポリフェノールーセファロース 4B ビーズと結合しなかったタンパク質を洗浄で除去し た後，(4)特異的抗体を用いたウェスタンブロット法によ

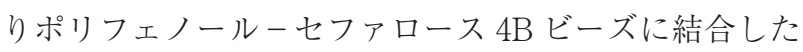
タンパク質を検出することができる（Fig. 1a）。

\section{$2 \cdot 2$ ポリフェノールとタンパク質の結合親和力の算出}

ポリフェノールには複数のタンパク質と結合する可能 性があり，これらの候補標的分子との結合親和力を比較 する必要がある。低分子化合物とタンパク質の相互作用 を解析する代表的な手法として, 表面プラズモン共鳴 (SPR) 法, 等温滴定型熱測定（ITC）法，及び水晶発 振子マイクロバランス $(\mathrm{QCM})$ 法などが知られている。 SPR 法はセンサーチップ上の質量変化を SPR により生 じる反射光の消失角度の变化として検出することで物質 間の結合特異性や結合親和性を解析する手法である。結 合速度定数 $(\mathrm{ka})$, 解離速度定数 $(\mathrm{kd})$, 解離定数 ( $\mathrm{KD}$ $=\mathrm{kd} / \mathrm{ka}$ ）を算出することができ，一度に得られる情報 の多さなどから，分子間相互作用の解析で長年にわたり 利用されている ${ }^{11)}$ 。ITC 法は分子間で結合が起きた際 に生じる発熱または吸熱の熱変化を直接測定すること で，分子間の相互作用を定量的に検出する手法で，熱を プローブとしているため，蛍光標識などによる化学的修 飾や物理的固定化などを必要とせず，天然に近い環境下 で分子間相互作用を解析することができる ${ }^{12)}$ 。また, 相互作用の解離定数 (KD), 結合比 (n), エンタルピー 変化 $(\Delta \mathrm{H})$, エントロピー変化 $(\Delta \mathrm{S})$ を求め, 物質の構 造変化や結合数, 種類を予測することで分子間相互作用 の機序を解明することも可能である。QCM 法は水晶発 振子という極薄い板状の水晶板に金属薄膜を取り付けた 電極に交流電圧を与え, 一定周波数で振動する性質を利 用した手法である。水晶発振子の周波数変化を検出する ことで, 電極上での物質の質量変化を計測し, 物質間の 結合強度を調べることができる ${ }^{13)}$ 。具体的には，(1)水
晶発振子を利用したセンサーチップに目的のタンパク質 を固定し, (2)ポリフェノールの濃度を変えながら結合 バッファーに添加し, (3)ポリフェノールが結合する際の 振動周波数の変化を測定することで, 結合解離定数 $(\mathrm{ka})$, 解離速度定数 $(\mathrm{kd})$, 解離定数 $(\mathrm{KD})$ を算出す る(Fig. 1b $)^{10)}$ 。このように SPR, ITC 及び QCM 法では, ポリフェノールとタンパク質間の親和性を示す解離定数 を求めることができる。解離定数が小さいほど親和性は 高くなるため, ポリフェノールとタンパク質間の結合特 異性を示すのにも有用である。また, これらの手法は非 標識状態の分子で相互作用を調べるので, より天然に近 い状態での結合を解析できるという利点がある。

\section{2・3 In silico シミュレーションによるポリフェノール とタンパク質の結合部位の推定}

細胞内信号伝達系の活性化を阻害剂が抑制する時, リ ン酸化に伴うタンパク質立体構造変化の阻止, ATP 結 合領域に結合することによる ATP 結合の阻止, 受容体 の多量体化やリガンド結合の阻止, 上流のタンパク質結 合ドメインに相補的に働くことによる活性化阻止など， 多くの抑制パターンが考えられる。ポリフェノールと標 的分子の結合様式を把握することは, その抑制機構を正 しく認識する上で非常に重要な点である。その結合を把 握する手段として, ポリフェノールータンパク質複合体 のX線結晶構造解析や NMR 構造解析があげられる。 しかしながら, ポリフェノールとタンパク質が結合した 状態での結晶を得るのは, 高度な技術および特殊な機器 が必要となるので簡便な方法とは言い難い。一方で, 多 くのタンパク質の X 線結晶構造解析や NMR 構造解析 のデータは Protein Data Bank (PDB : http://www. $\mathrm{rcsb}$.org/pdb/）に蓄積され, 無料で利用することがで きる。これらの情報を基に, In silico シミュレーション によるタンパク質と低分子化合物間の相互作用が分析で きる 3 次元ファーマコフォアモデル解析ソフトが開発さ れ，ドラッグデザイン等を目的として広く用いられてい る ${ }^{14)}$ 。その一つである Molecular Operating Environment (MOE) は，低分子から高分子まで多様な分子モデルを 構築することができ, タンパク質と低分子化合物の相互 作用の検討，リガンドデザインなどに多用されている。 我々はポリフェノールとタンパク質の結合部位推定に MOEを用いている。その解析手順（Fig. 1c）は, (1) $\mathrm{PDB}$ から目的のタンパク質の結晶構造をダウンロード し, 結晶構造中の結晶水やタンパク質の構造に関連のな い分子を削除する。(2)タンパク質に水素原子の付加及び 位置の最適化をして立体構造を安定化させ，ポリフェ ノールとタンパク質の結合をドッキングするのに適した 力場 $(\mathrm{MMFF} 94 \mathrm{x})$ に設定し, リガンド結合部位の候補 
を目的のタンパク質上に検出する。(3)候補部位とポリ フェノール間のドッキングシミュレーションを行い, 計 算されたデータに従って, ポリフェノールとタンパク質 の分子モデルを作成する。

このようにして MOE で構築された分子モデルは，プ ルダウンアッセイや結合親和力解析で検証したポリフェ ノールータンパク質複合体の結合部位を推定したもので ある。

\section{3 ポリフェノールの分子標的}

細胞における細胞信号伝達系は, タンパク質間でリン 酸化・分解・結合などを起こすことにより細胞外環境を 細胞内に伝え，環境に応じた細胞内反応を示すために必 要となる生体内反応である。細胞外環境因子は, まず細 胞膜上の受容体で感知され，その受容体に対応した下流 の細胞信号伝達系タンパク質が反応し，最終的に標的と なる特定の転写因子を制御することで外部刺激に応じる 遺伝子の発現を導く。主な受容体としては上皮成長因子
受容体 (EGFR), G タンパク質共役型受容体 (GPCR), インスリン受容体, サイトカイン受容体, Toll 様受容体 (TLR4 など), 細胞死受容体 (Fas, TNF $\alpha$ R) などが知 られている。その下流には, MAPK 経路, NF-кB 経路, PI3K-Akt 経路, JAK-STAT 経路, アポトーシス経路, AMPK 経路，mTOR 経路など多数の経路が存在し，そ れらは上下の関係のみならず，別経路とのクロストーク も多い。これらの経路を介して転写因子(AP-1, NF-кB， STAT, CREB， Myc，Rbなど）を活性化する ことで目的遺伝子の発現を制御している。ポリフェノー ルは，これらのタンパク質のリン酸化や分解を制御する ことで, 細胞信号伝達系を制御することが多く報告され ており 10，15，16），本章は，これまでに報告されているポ リフェノールの直接的な分子標的に関する研究例をまと めて紹介する（Table 1)。

\section{$3 \cdot 1$ フラボノール類の分子標的}

フラボノール類は果物や野菜の中に広く存在してお り, 高い抗酸化作用や抗変異作用など多くの生理機能に

Table 1 ポリフェノールの分子標的

\begin{tabular}{|c|c|c|}
\hline Group & Polyphenol & Direct binding protein* \\
\hline \multirow{8}{*}{ Flavonols } & Myricetin & $\begin{array}{l}\text { JAK1 }^{17}, \text { STAT3 }^{17}, \text { PI3K }^{18,19}, \text { Akt }^{20}, \text { Raf }^{21}, \text { MEK1 }^{22}, \text { MKK4 }^{23}, \text { Fyn }^{24} \text {, } \\
\text { GLP-1R }\end{array}$ \\
\hline & Quercetin & Raf- $1^{26}, \mathrm{MEK}^{26,27}, \mathrm{ERK} 1 / 2^{27}, \mathrm{SEK}^{27}, \mathrm{JNK} 1 / 2^{27}, \mathrm{RSK}^{28}, \mathrm{PI}^{2 \mathrm{~K}}{ }^{19,29}$ \\
\hline & Rutin & $\mathrm{EGFR}^{30}$ \\
\hline & Isorhamnetin & $\mathrm{MEK1}^{28,31}, \mathrm{PI} 3 \mathrm{~K}-\mathrm{p} 110^{31}$ \\
\hline & 8-Prenylquercetin & $\mathrm{SEK}^{27}, \mathrm{JNK} 1 / 2^{27}, \mathrm{MEK}^{27}, \mathrm{ERK} 1 / 2^{27}$ \\
\hline & Kaempferol & $\mathrm{RSK}^{32,33}, \mathrm{MSK}^{32}, \mathrm{Src}^{34}, \mathrm{PI} 3 \mathrm{~K}-\mathrm{p} 85^{35}$ \\
\hline & 5-Deoxykaempferol & PI3K-p85 ${ }^{36}, \mathrm{Src}^{36}, \mathrm{RSK}^{36}$ \\
\hline & Fisetin & $\mathrm{CDK}^{37}$ \\
\hline Flavones & Luteolin & $\mathrm{PKC} \varepsilon^{38}, \mathrm{Src}^{38}$ \\
\hline Flavanonols & Taxifolin & $\mathrm{EGFR}^{39}, \mathrm{PI} 3 \mathrm{~K}-\mathrm{p} 110^{39}, \mathrm{Src}$ (in vitro only) ${ }^{39}$ \\
\hline \multirow{3}{*}{ Flavanols } & (-)-Epigallocatechin gallate (EGCG) & $\begin{array}{l}\text { 67LR }{ }^{40}, \text { IGF-IR }^{41}, \text { Notch }^{42}, \text { GRP78 }^{43}, \text { ZAP-70 }^{44}, \text { Fyn }^{45}, \text { HSP90 }^{46}, \\
\text { G3BP1 }^{47}, \text { miR-33a/-122 }\end{array}$ \\
\hline & Theasinensin A & $\mathrm{MEK}^{48}, \mathrm{ERK}^{48}$ \\
\hline & Procyanidin B2 & $\mathrm{MEK}^{49}, \mathrm{MKK}^{50}$ \\
\hline \multirow{3}{*}{ Anthocyanins } & Delphinidin & $\begin{array}{l}\text { PI3K-p110 } 0^{51}, \text { Raf- }^{52}, \text { B-Raf }^{53}, \text { MEK1 }^{52,53}, \text { ERK1 }^{2} 2^{53}, \text { Fyn }^{54}, \text { Era }^{55} \text {, } \\
\text { MAPKK4 }^{51}\end{array}$ \\
\hline & Cyanidin & Raf- $^{56}, \mathrm{MKK}^{56}, \mathrm{MEK1}^{56}$ \\
\hline & Delphinidin 3-sambubioside (Dp3-sam) & (p-) $\operatorname{MEK1}^{53},(\mathrm{p}-) \mathrm{B}_{\mathrm{Raf}}{ }^{53},(\mathrm{p}-) \mathrm{ERK} 1 / 2^{53}$ \\
\hline Isoflavones & 7,3','-Trihydroxyisoflavone (7,3',4'-THIF) & PI3K-p110 $0^{58}, \mathrm{CDK} 2 / 4^{58}$ \\
\hline Isoflavandiols & Equol & $\mathrm{MEK1}^{57}$ \\
\hline \multirow[t]{2}{*}{ Stilbenes } & Resveratrol & $\begin{array}{l}\mathrm{COX}^{59}{ }^{59}, \mathrm{MEK1}^{60}, \mathrm{LTA}_{4} \mathrm{H}^{61}, \mathrm{PPAR \alpha}^{68}, \mathrm{PPAR}^{62}, \mathrm{mTOR}^{63}, \mathrm{miR}- \\
33 \mathrm{a} /-122^{66}\end{array}$ \\
\hline & Piceatannol & $\mathrm{JAK} 1^{17}$ \\
\hline \multirow{2}{*}{ Phenolic acids } & Caffeic acid & Fyn $^{64}$ \\
\hline & [6]-Gingerol & $\mathrm{LTA}_{4} \mathrm{H}^{65}$ \\
\hline
\end{tabular}

*上付数字は, 参考論文の番号である。 
関連し, 同定されている標的分子化合物も多く存在して いる。その中で, $\mathrm{B}$ 環に水酸基を有するケンフェロール (4’ 位)，クエルセチン（3，4'位)，ミリセチン（3， 4’, 5 位）は，基本骨格が同じで水酸基の数だけが異なるた め, 水酸基の数による生物活性や標的分子の比較に適し ている。例えば, 正常細胞をがん細胞へと突然変異させ る細胞形質転換への抑制効果は，水酸基の多い順に抑制 効果が強い（ミリセチン>クエルセチン>ケンフェロー ル)。

ミリセチンは, JAK-STAT 経路の JAK1 と STAT3 ${ }^{17)}$, PI3K-Akt 経路の $\mathrm{PI} 3 \mathrm{~K}^{18,}{ }^{19)}$ と $\mathrm{Akt}^{20)}, \mathrm{MAPK}$ 経路の $\mathrm{Raf}^{21)}, \mathrm{MEK}^{22)}{ }^{22}, \mathrm{MKK}_{4}{ }^{23)}$ ，他にも $\mathrm{Fyn}^{24)}$ といった細 胞信号伝達系のタンパク質と直接結合することが知られ ている。具体的には, 上皮増殖因子（EGF）誘導性の 細胞形質転換に重要な細胞内信号伝達系である EGFR $($ 受容体 $) \rightarrow$ JAK1（キナーゼ） $\rightarrow$ STAT3（転写因子）経 路において，ミリセチンはEGFR には結合せず，JAK1 及びSTAT3に直接結合することが明らかになってい る。なかでも JAK1への結合作用の方が STAT3よりも 強く，その触媒領域に結合することから，ミリセチンは 細胞内でまず JAK1に結合し触媒領域を制御することで 活性を抑制し，下流のSTAT3 の活性も抑えていると考 えられる。JAK1の特異的阻害剂として知られているピ セアタンノールを用いて同様の実験を行った結果, 驚く ベきことにミリセチンはピセアタンノールよりも強い活 性を持つことが示された。さらに, 上記のin silicoシミュ レーションで得られた分子結合モデルから，ミリセチン がATP結合競合阻害分子として, PI3K $\gamma^{19)}, \mathrm{Akt}^{20)}$, $\mathrm{MKK}^{23)}$ 及び $\mathrm{Fyn}^{24)}$ の活性を制御することが明らかと なり，また近年ではミリセチンが 2 型糖尿病に重要な役 割を示すグルカゴン様ペプチド受容体への直接結合・抑 制効果も報告されている ${ }^{25)}$ 。

クエルセチンは, 生理機能がよく研究されている食品由 来化合物の一つであり, $\mathrm{Raf}^{2} \mathrm{1}^{26)}, \mathrm{MEK}^{26,27)}, \mathrm{ERK} 1 / 2^{27)}$, $\mathrm{SEK}^{27)}$ ，JNK1/2 $2^{27)}, \mathrm{RSK}_{2}{ }^{28)}$ ，及び $\mathrm{PI} 3 \mathrm{~K}^{19,29)}$ が分子標 的として知られている。興味深いことに, クエルセチン はPI3K の特異的阻害剤である LY294002 と同じATP 結合領域に結合し，PI3K に結合する際の解離定数を比 較するとほぼ同等であることが示されている（クエルセ チン $=0.28 \mu \mathrm{M}, \mathrm{LY} 294002=0.21 \mu \mathrm{M})$ 。そこで, 分子結 合モデルで結合様式を比較すると, クエルセチンは LY294002 を反転したように結合することから，標的夕 ンパク質への結合様式のわずかな違いで抑制効果が変わ ることが示唆された ${ }^{19)}$ 。また, クエルセチンの 3 位の 酸素に $\beta$-ルチノースが結合した配糖体であるルチンが, ATP 競合阻害的に EGFRに結合して下流の COX-2 発
現を抑制することや ${ }^{30)}$ ，クエルセチンの 3 位の酸素に メチル基が結合したイソラムネチンが，ATP 競合阻害 的に MEK1 と PI3K に結合して EGF 誘導性の細胞形質 転換を抑制することも報告されている ${ }^{31)}$ 。さらに，本 研究室においては, クエルセチンの誘導体である 8- プ レニルクエルセチン (8-PQ) の抗炎症作用機構を解析し, 8-PQ が細胞膜上受容体である TLR4 とは競合せずに細 胞膜内に取り込まれて, MAPKs のSEK1, JNK1/2, MEK1，ERK1/2 と直接的結合し，それらのリン酸化を 抑制することを明らかにした ${ }^{27)}$ 。また， 8-PQがクエル セチンよりも強い抗炎症作用を示すのは, それらの細胞 吸収率の差によるものであると考えられることも示唆さ れた。

ケンフェロールにも抗がん作用があることは報告され ており，がん細胞で高い活性が見られる RSK2 や MSK1 に直接結合し ATP 結合活性阻害を起こすことが知られ ている ${ }^{32,33)}$ 。また Src とも直接結合し ATP 結合活性阻 害を起こすことで, COX-2 発現を抑制する ${ }^{34)}$ 。さらに PI3K-p85 サブユニットに結合し，下流の Aktの活性も 抑制する ${ }^{35)}$ 。ケンフェロールの 5 位の水酸基が水素に 置換された5-deoxykaempferol は, PI3K-p85 サブユニッ ト及び Src, RSK2 へ結合し, UVB 誘導性の COX-2 や VEGF の発現を抑えて皮膚ガンの変異を抑制するが, 分 子標的間の結合比較はわかっていない ${ }^{36)}$ 。PI3K は 3 種 類全てのフラボノールが結合するので, フラボノール構 造に共通する重要な分子標的の一つであることが言え る。

同じフラボノールでもさらにフィセチンは細胞周期や 細胞死などに関与する CDK6 に対し, 既知の CDK 特異 的阻害剂と同様に，ヒンジ領域に水素結合し活性を抑制 する ${ }^{37)}$ 。このよにポリフェノール化合物の中でも, フラボノール系化合物はもっとも分子標的が同定されて いるグループである。

\section{$3 \cdot 2$ フラボン類の分子標的}

フラボン類は, 野菜やハーブに多く含まれており, 高 い抗酸化作用を有している。代表的な化合物であるルテ オリンは, PKC\&や Src と ATP 競合的に結合することで, 下流の MAPKs や Akt シグナル活性を抑制し, UVB 誘 導性のがん誘導を抑制する ${ }^{38)}$ 。

\section{$3 \cdot 3$ フラバノノール類の分子標的}

フラバノノール類は, 代表的な化合物としてジヒドロ クエルセチンとして知られるタキシフォリンがあり, 抗 酸化や抗炎症効果に加え，心疾患予防効果などが報告さ れている。タキシフォリンは受容体の一つである EGFR や PI3K-p110 サブユニットに ATP 競合的に結合する ${ }^{39)}$ 。 活性抑制効果としては，PI3Kより EGFRに対して強く 
抑制効果がみられる。

\section{$3 \cdot 4$ フラバノール類の分子標的}

フラバノール類は，お茶に多く含まれるカテキン類が よく知られており，特に緑茶に多く含まれている（一) -epigallocatechin-3-gallate (EGCG) は, 強力な抗酸化 活性や腫瘍抑制作用など，多くの生理作用が報告されて いる。その標的分子の一つとして，基底膜の主要成分ラ ミニンに結合する細胞膜タンパクであり悪性度の高いが ん細胞に高頻度に発現する $67 \mathrm{KDa}$ ラミニンレセプター （67LR）が同定された ${ }^{40)}$ 。その結合部位は 67LR のアミ ノ酸残基 161 - 170 番目であり，これはラミニン結合部 位（173-178）やプリオン結合部位（161-179）と関連 し，その抑制作用が結合阻害活性からくるものであるこ とが示唆される。EGCGはこのように細胞の表面に結合 することが多く，腫瘍形成に働く IGF-IR ${ }^{41)}$ や最近では Notch 受容体との結合も報告されている ${ }^{42)}$ 。他にも分子 標的として報告されている $\mathrm{GRP} 78^{43)}$ は小胞体に常在す る分子シャペロンで，近年 IGF-IR との相互作用も報告 されている他, ZAP-70 ${ }^{44)}$ やFyn ${ }^{45)}$, HSP90 ${ }^{46)}, \mathrm{G}^{2} \mathrm{BP} 1^{47)}$ との結合も報告されている。

お茶の加工をする際, 発酵が進むことでカテキンの重 合体が形成されることが知られており，特にウーロン茶 に多く含まれる重合体として 5 種類のテアシネンシン (A， B， C， D， E) がある。その中でもテアシネンシ ン $\mathrm{A}$ は最も強い炎症抑制効果をもつ。近年, 当研究室 では COX-2 を強く抑制するテアシネンシンAの分子標 的としてその上流の MAPKs である, MEK1 と ERK1/2 を同定した ${ }^{48)}$ 。QCM 法により結合解離定数を比較した ところ ERK2 の方がより強く結合することから， ERK2 がテアシネンシン Aの最初の分子標的となっていると 考えられる。また 2 量体のカテキンであるプロシアニジ ン B 2 は, ココアやチョコレート・赤ワイン・フルーツ ジュースなどの食品加工物に多く含まれ，抗酸化作用や 抗腫瘍形成, DNA 損傷の予防効果などが知られている。 その分子標的としてはテアシネンシン $\mathrm{A}$ と同じく, $\mathrm{MEK1}^{49)}$ や $\mathrm{MKK} 4^{50)}$ が知られている。

\section{$3 \cdot 5$ アントシアニン類の分子標的}

アントシアニン類は, 強い水溶性色素をもつフラボノ イドの一種で正電荷を持ち，果実や花などを中心に植物 界に広く存在しており，抗酸化作用の強い食品成分とし て知られている。その一種であるデルフィニジンは PI3K-p110 ${ }^{51)}$ を始め, Raf1 ${ }^{52)}$, B-Raff ${ }^{53)}, \mathrm{MEK}^{52,53)}$, $\mathrm{ERK} 1 / 2^{53)}, \mathrm{MAPKK} 4^{51)}$ 及び $\mathrm{Fyn}^{54)}$ の他, $\mathrm{ER} \alpha$ 受容体 ${ }^{55)}$ への結合も知られている。近年, 当研究室ではデルフィ

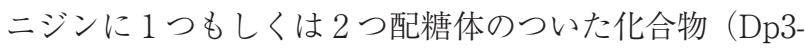
Sam 及び Dp3-Lat-5-Glu）との構造比較解析を行った。
MEK1 との直接結合作用を比較した結果, デルフィニ ジン及び Dp3-Sam は MEK1 と直接結合するが Dp3-Lat5-Glu は結合しないことがわかった。このことからデル フィニジンにおいては, 配糖体の数が標的分子との結合 （力）には関連ないことが示された ${ }^{53)}$ 。デルフィニジン よりも $\mathrm{B}$ 環の水酸基が一つ少ないシアニジンは, Raf, MKK4，MEK1 ${ }^{56)}$ との結合が明らかになっている。

\section{$3 \cdot 6$ イソフラボン類とその代謝産物の分子標的}

イソフラボン類は, 大豆などのマメ科の植物に多く含 まれており，代表的な化合物としてゲニステインやダイ ゼインが知られている。ゲニステインは，ATP と競合 的に作用し，EGFRの活性阻害することにより，MAPK や PI3K を制御することが知られている ${ }^{15)}$ 。ダイゼイン の代謝産物であるエクオールは, 抗酸化作用や抗がん作 用においてダイゼインよりも強い活性を持つことがわ かっており，TPA 及び EGF 誘導性の細胞形質転換を抑 制し，分子標的としては MEK1 が報告されている ${ }^{57)}$ 。 MEK1 とはATP 競合阻害はしないが， N 末側の MEK1 と強く結合しており，これは MEK1 特異的阻害剂 PD184351 の結合様式と非常に似ている。またダイゼイ ンの別の代謝産物の 7, 3', 4'-THIF は, PI3K と $\mathrm{CDK} 2 / 4$ にATP 非競合的に結合し，それらの活性を抑 制することで，下流の Akt 経路の抑制，最終的に cell cycleの進行を G1 期で止める。しかしながら, PI3K と CDKのどちらにより強く結合するかはわかっていない ${ }^{58)}$

\section{$3 \cdot 7$ スチルベノイドポリフェノールの分子標的}

スチルベノイドポリフェノールの一種であるレスベラ トロール $(\mathrm{RSVL})$ は,ブドウや赤ワインに存在しており， 腫瘍形成を抑制することによる抗がん作用が知られてい る。他に 2 つアナログ, RSVL2 と 3 が知られている。 RSVL と RSVL2 には高い COX-2 発現抑制, PGE2 抑制, 突然変異形成抑制効果が示され，RSVL3にはほとんど ない。大きな違いは水酸基の付加（RSVL， RSVL2）か メトキシ基（RSVL3）の付加かによるが，これらの生 理活性には水酸基が重要であるように示唆される。また COX-2への直接結合も RSVL と RSVL2のみにみられ る ${ }^{59)}$ 。とくにRSVL2 は, RSVLの 10 倍以上の抗形質 転換作用が知られており，RSVLには結合しないが RSVL2にのみ分子標的として MEK1が同定されてい る ${ }^{60)}$ 。RSVLの多く含まれる赤ワイン抽出液では高い MEK1/ERK2 抑制効果がみられるが, これは RSVLで はなくRSVL2の関与が高いことが示唆される。さらに 亜鉛酵素の一つである LTA4H にも RSVL は直接結合・ 抑制し, 腫瘍成長抑制を示す ${ }^{61)}$ 。他にも RSVL の分子 標的として, PPAR $\gamma$ のリ゙ンド結合領域 ${ }^{62)}$ や mTOR が報告されている ${ }^{63)}$ 。よく知られたアナログの一つで 
あるピセアタンノールは JAK1 阻害剤であるが, 先述の ようにJAK1 に直接結合することで下流のSTAT3 の転 写活性を抑制する ${ }^{17)}$ 。

\section{$3 \cdot 8$ その他のポリフェノールの分子標的}

フェノール酸は, 色素以外のポリフェノール化合物で あり, クロロゲン酸やエラグ酸などが含まれる。代表的 な化合物として, クロロゲン酸の一種であるカフェイン 酸は, 果物, 野菜, 穀物, コーヒーなどから取れる主要 な化合物であり, アルツハイマー病やパーキンソン病, 糖尿病や心臓病に効果があるとされ, 死亡率の抑制に関 係することが示唆されている。カフェイン酸がUVB 誘 導性の COX-2 発現, PGE2 発現抑制にその上流にある MAPKs の活性を抑制することがわかっているが，その 直接的な分子標的はさらに上流の Src ファミリーの一つ である Fyn である ${ }^{64)}$ 。ATP 競合阻害的には働かないが, 触媒領域に結合するためFynの活性を抑えて, 下流の MAPKs の活性化を制御していると考えられる。

[6]- ジンジェロールは主要な生姜の食品成分で, 抗酸 化や抗炎症, 抗変異活性などが報告されている。がん治 療において, 前述の LTA4H は魅力的な分子標的であり, 大腸ガンに重要な役割を果たすと考えられ，[6]- ジン ジェロールは LTA4H に直接結合することで, 複数の大 腸ガン細胞のがん活性を抑えることがわかっている ${ }^{65)}$ 。

\section{4 分子標的同定の問題点と将来展望}

本総説では, ポリフェノールが機能発現する際の細胞 内信号伝達系における同定された分子標的について述べ てきた。前項で示したように，食品由来成分であるポリ フェノールは特異的阻害剂とは異なり, 特異的阻害能が 弱く，標的分子が多いという“広く浅い”特徵がある。 このことがポリフェノールを日常的に食物から摂取する ことにより, 幅広い病気の予防や進行の緩和に役割を果 たしているのは理解しやすい。しかしながら, ポリフェ ノールは生体内での吸収性が低いことや, 種々の腸内細 菌叢酵素によって代謝を受けるため, ポリフェノール 自身が実験系と同じように，生体内で直接的に機能発現 に寄与しているとは必ずしもいえない。例えば，大豆イ ソフラボンの一種であるダイゼインは, 生体内で腸内細 菌によりエクオールや 7, 3, 4'-THIF に代謝され, こ れらの代謝産物が細胞信号伝達関連タンパク質と直接相 互作用することで機能発現に寄与するという報告がされ ている ${ }^{57,58)}$ 。近年, 体内に存在する代謝産物を網羅的 に解析できるメタボローム分析手法が進んでおり, 高感 度で代謝産物の分子量及び含有量を知ることができ，さ らに MS/MS 分析による電気的開裂により，部分構造を 実測のデータベース（MassBank：www.massbank.jp）
や化合物予測ツールから推定することができる。このよ うに生体内で代謝されたポリフェノールの構造をメタボ ロームの解析手法により推定することが可能となり,さ らにその複数の分子標的を同時に同定することも可能と なることから, メタボローム解析は今後のポリフェノー ルの機能性発現と生体内標的分子との関係解明の足がか りになると期待される。また，近年遺伝子の発現を制御 する新たな仕組みとして, エピジェネティックな制御及 び microRNA（miRNA）の制御も注目されており，レ スベラトロールや EGCG が miR-33 及び miR-122 に直接 結合し，代謝調節に関与していることが報告されてい る ${ }^{66)}$ 。今後もポリフェノールの機能性発現と miRNA 等 の制御関係の解明にも期待したい。

\section{文 献}

1) Hollman, P. C.; Katan, M. B. Food Chem. Toxicol., 37, 937-942 (1999).

2) Tomás-Barberán, F.A.; Andrés-Lacueva, C. J. Agric. Food Chem., 60, 8773-8775 (2012).

3) Rice-Evans, C. Curr. Med. Chem., 8, 797-807 (2001).

4) Fraga, C. G.; Galleano, M.; Verstraeten, S. V.; Oteiza, P. I. Mol. Aspects Med., 31, 435-445 (2010).

5) Hollman, P. C. Arch. Biochem. Biophys., 559, 100-105 (2014).

6) Ramos, S. Mol. Nutr. Food Res, 52, 507-526 (2008).

7) Teillet, F.; Boumendje, A.; Boutonnat, J.; Ronot, X. Med. Res. Rev., 28, 715-745 (2008).

8) David, G. S.; Chino, T. H.; Reisfeld, R. A. FEBS Lett., 43, 264-266 (1974).

9) Kadonaga, J. T.; Tjian, R. Proc. Natl. Acad. Sci. USA, 83, 5889-5893 (1986).

10) Hou, D.-X.; Kumamoto, T. Antioxid. Redox. Signal, 13, 691-719 (2010).

11）Karlsson, R. J. Mol. Recognit., 17, 151-161 (2004).

12) Callies, O.; Hernández Daranas, A. Nat. Prod. Rep., 33, 881-904 (2016).

13) Cooper, M. A.; Singleton, V. T. J. Mol. Recognit., 20, 154-184 (2007).

14) Wolber, G., Seidel, T., Bendix, F., Langer, T. Drug Discov. Today, 13, 23-29 (2008).

15) Kang, N. J.; Shin, S. H.; Lee, H. J.; Lee, K. W. Pharmacol. Ther., 130, 310-324 (2011).

16) Lee, K. W.; Bode, A. M.; Dong, Z. Nat. Rev. Cancer, 11, 211-218 (2011).

17) Kumamoto, T.; Fujii, M.; Hou, D. X. Cancer Lett., 275, 17-26 (2009).

18) Jung, S. K.; Lee, K. W.; Byun, S.; Lee, E. J.; Kim, J. E.; Bode, A. M.; Dong, Z:; Lee, H. J. Carcinogenesis, 31, 911-917 (2010).

19) Walker, E. H.; Pacold, M. E.; Perisic, O.; Stephens, L.; Hawkins, P. T.; Wymann, M. P.; Williams, R. L. Mol. Cell, 6, 909-919 (2000).

20) Kumamoto, T.; Fujii, M.; Hou, D. X. Mol. Cell. Bio- 
chem., 332, 33-41 (2009).

21) Jung, S. K.; Lee, K. W.; Kim, H. Y.; Oh, M. H.; Byun, S.; Lim, S. H.; Heo, Y. S.; Kang, N. J.; Bode, A. M.; Dong, Z.; Lee, H. J. Biochem. Pharmacol., 79, 1455-1461 (2010).

22) Lee, K. W.; Kang, N. J.; Rogozin, E. A.; Kim, H. G.; Cho, Y. Y.; Bode, A. M.; Lee, H. J.; Surh, Y. J.; Bowden, G. T.; Dong, Z. Carcinogenesis, 28, 1918-1927 (2007).

23) Kim, J. E.; Kwon, J. Y.; Lee, D. E.; Kang, N. J.; Heo, Y. S.; Lee, K. W.; Lee, H. J. Biochem. Pharmacol., 77, 412-421 (2009).

24）Jung, S. K.; Lee, K. W.; Byun, S.; Kang, N. J.; Lim, S. H.; Heo, Y. S.; Bode, A. M.; Bowden, G. T.; Lee, H. J.; Dong, Z. Cancer Res., 68, 6021-6029 (2008).

25) Li, Y.; Zheng, X.; Yi, X.; Liu, C.; Kong, D.; Zhang, J.; Gong, M. FASEB J., 31, 2603-2611 (2017).

26) Lee, K. W.; Kang, N. J.; Heo, Y. S.; Rogozin, E. A.; Pugliese, A.; Hwang, M. K.; Bowden, G. T.; Bode, A. M.; Lee, H. J.; Dong, Z. Cancer Res, 68, 946-955 (2008).

27) Hisanaga, A.; Mukai, R.; Sakao, K.; Terao, J.; Hou, D.-X. Mol. Nutr. Food Res., 60, 1020-1032 (2016).

28) Chen, H.; Yao, K.; Nadas, J.; Bode, A. M.; Malakhova, M.; Oi, N.; Li, H.; Lubet, R. A.; Dong, Z. PLos One, 7, e38261 (2012).

29) Hwang, M. K.; Song, N. R.; Kang, N. J.; Lee, K. W.; Lee, H. J. Int. J. Biochem. Cell Biol., 41, 1592-1600 (2009).

30) Choi, S.; Lim, T. G.; Hwang, M. K.; Kim, Y. A.; Kim, J.; Kang, N. J.; Jang, T. S.; Park, J. S.; Yeom, M. H.; Lee, K. W. Biochem. Parmacol., 86, 1468-1475 (2013).

31) Kim, J. E.; Lee, D. E., Lee, K. W.; Son, J. E.; Seo, S. K.; Li, J.; Jung, S. K.; Heo, Y. S.; Mottamal, M.; Bode, A. M.; Dong, Z.; Lee, H. J. Cancer Prev. Res. (Phila), 4, 582591 (2011).

32) Yao, K.; Chen, H.; Liu, K.; Langfald, A., Yang, G.; Zhang, Y.; Yu, D. H.; Kim, M. O.; Lee, M. H.; Li, H.; Bae, K. B.; Kim, H. G.; Ma, W. Y.; Bode, A. M.; Dong, Z.; Dong, Z. Cancer Prev. Res. (Phila), 7, 958-967 (2014).

33) Cho, Y. Y.; Yao, K.; Pugliese, A.; Malakhova, M.L.; Bode, A. M.; Dong Z. Cancer Res., 69, 4398-4406 (2009).

34) Lee, K. M.; Lee, K. W.; Jung, S. K.; Lee, E. J.; Heo, Y. S.; Bode, A. M.; Lubet, R. A.; Lee, H. J.; Dong Z. Biochem. Pharmacol., 80, 2042-2049 (2010).

35) Lee, K. M.; Lee, D. E.; Seo, S. K.; Hwang, M. K.; Heo, Y. S.; Lee, K. W.; Lee, H. J. Carcinogenesis, 31, 1338-1343 (2010).

36) Lee, K. M.; Lee, K. W.; Byun, S.; Jung, S. K.; Seo, S. K.; Heo, Y. S.; Bode, A. M.; Lee, H. J.; Dong, Z. Cancer Prev. Res. (Phila), 3, 454-465 (2010).

37) Lu, H.; Chang, D. J.; Baratte, B.; Meijer, L.; SchulzeGahmen, U. J. Med. Chem., 48, 737-743 (2005).

38) Byun, S.; Lee, K. W.; Jung, S. K.; Lee, E. J.; Hwang, M. K.; Lim, S. H.; Bode, A. M.; Lee, H. J.; Dong, Z. Cancer Res., 70, 2415-2423 (2010).

39) Oi, N.; Chen, H.; Ok Kim, M.; Lubet, R. A.; Bode, A. M.; Dong, Z. Cancer Prev. Res. (Phila), 5, 1103-1114(2012).

40) Tachibana, H.; Koga, K.; Fujimura, Y.; Yamada, K. Nat. Struct. Mol. Biol., 11, 380-381 (2004).
41) Li, M.; He, Z.; Ermakova, S.; Zheng, D.; Tang, F.; Cho, Y. Y.; Zhu, F.; Ma, W. Y.; Sham, Y.; Rogozin, E. A.; Bode, A. M.; Cao, Y.; Dong, Z. Cancer Epidemiol. Biomarkers Prev., 16, 598-605 (2007).

42) Wang, T.; Xiang, Z.; Wang, Y.; Li, X.; Fang, C.; Song, S.; Li, C.; Yu, H.; Wang, H.; Yan, L.; Hao, S.; Wang, X.; Sheng, J. Front. Immunol., 8, 433 (2017).

43) Ermakova, S. P.; Kang, B. S.; Choi, B. Y.; Choi, H. S.; Schuster, T. F.; Ma, W. Y.; Bode, A. M.; Dong, Z. Cancer Res., 66, 9260-9269 (2006).

44) Shim, J. H.; Choi, H. S.; Pugliese, A.; Lee, S. Y.; Chae, J. I.; Choi, B. Y.; Bode, A. M.; Dong, Z. J. Biol. Chem., 283, 28370-28379 (2008).

45) He. Z.; Tang, F.; Ermakova, S.; Li, M.; Zhao, Q.; Cho, Y. Y.; Ma, W. Y.; Choi, H. S.; Bode, A. M.; Yang, C. S.; Dong, Z. Mol. Carcinog., 47, 172-183 (2008).

46) Palermo, C. M.; Westlake, C. A.; Gasiewicz, T. A. Biochemistry, 44, 5041-5052 (2005).

47) Shim, J. H.; Su, Z. Y.; Chae, J. I.; Kim, D. J.; Zhu, F.; Ma, W. Y.; Bode, A. M.; Yang, C. S.; Dong, Z. Cancer Prev. Res. (Phila), 3, 670-679 (2010).

48) Hisanaga, A.; Ishida, H.; Sakao, K.; Sogo, T.; Kumamoto, T.; Hashimoto, F.; Hou, D.-X. Food Funct., 5, 1891-1897 (2014).

49) Kang, N. J,; Lee, K. W.; Lee, D. E; Rogozin, E. A.; Bode, A. M.; Lee, H. J.; Dong, Z. J. Biol. Chem., 283, 2066420673 (2008).

50) Cho, E. S.; Jang, Y. J.; Kang, N. J.; Hwang, M. K.; Kim, Y. T.; Lee, K. W.; Lee, H. J. Free Radic. Biol. Med., 46, 1319-1327 (2009).

51) Kwon, J. Y.; Lee, K. W.; Kim, J. E.; Jung, S. K.; Kang, N. J.; Hwang, M. K.; Heo, Y. S.; Bode, A. M.; Dong, Z.; Lee, H. J. Carcinogenesis, 30, 1932-1940 (2009).

52) Kang, N. J.; Lee, K. W.; Kwon, J. Y.; Hwang, M. K.; Rogozin, E. A.; Heo, Y. S.; Bode, A. M.; Lee, H. J.; Dong, Z. Cancer Prev. Res. (Phila), 1, 522-531 (2008).

53) Sogo, T.; Kumamoto, T.; Ishida, H.; Hisanaga, A.; Sakao, K.; Terahara, N.; Wada, K.; Hou, D.-X. Planta Med., 81, 26-31 (2015)

54) Hwang, M. K.; Kang, N. J.; Heo, Y. S.; Lee, K. W.; Lee, H. J. Biochem. Pharmacol., 77, 1213-1222 (2009).

55) Chalopin, M.; Tesse, A.; Martinez, M. C.; Rognan, D.; Arnal, J. F.; Andriantsitohaina, R. Plos One, 5, e8554 (2010).

56） Kim, J. E.; Kwon, J. Y.; Seo, S. K.; Son, J. E.; Jung, S. K.; Min, S. Y.; Hwang, M. K.; Heo, Y. S.; Lee, K. W.; Lee, H. J. Biochem. Pharmacol., 79, 1473-1482 (2010).

57) Kang, N. J.; Lee, K. W.; Rogozin, E. A.; Cho, Y. Y.; Heo, Y. S.; Bode, A. M.; Lee, H. J.; Dong, Z. J. Biol. Chem., 282, 32856-32866 (2007).

58) Lee, D. E.; Lee, K. W.; Song, N. R.; Seo, S. K.; Heo, Y. S.; Kang, N. J.; Bode, A. M.; Lee, H. J.; Dong, Z. J. Biol. Chem., 285, 21458-21466 (2010).

59) Zykova, T. A.; Zhu, F.; Zhai, X.; Ma, W. Y.; Ermakova, S. P.; Lee, K. W.; Bode, A. M.; Dong, Z. Mol. Carcinog., 47, 797-805 (2008). 
60) Lee, K. W.; Kang, N. J.; Rogozin, E. A.; Oh, S. M.; Heo, Y. S.; Pugliese, A.; Bode, A. M.; Lee, H. J; Dong, Z. Int. J. Cancer, 123, 2487-2496 (2008).

61) Oi, N.; Jeong, C. H.; Nadas, J.; Cho, Y. Y.; Pugliese, A.; Bode, A. M.; Dong, Z. Cancer Res., 70, 9755-9764 (2010)

62) Calleri, E.; Pochetti, G.; Dossou, K. S.; Laghezza, A.; Montanari, R.; Capelli, D.; Prada, E.; Loiodice, F.; Massolini, G.; Bernier, M.; Moaddel, R. Chembiochem, 15, 1154-1160 (2014).

63) Park, D.; Jeong, H.; Lee, M. N.; Koh, A.; Kwon, O.; Yang, Y. R.; Noh, J.; Suh, P. G.; Park, H.; Ryu, S. H. Sci.
Rep., 6, 21772 (2016).

64) Kang, N. J.; Lee, K. W.; Shin, B. J.; Jung, S. K.; Hwang, M. K.; Bode, A. M.; Heo, Y. S.; Lee, H. J.; Dong, Z. Carcinogenesis, 30, 321-330 (2009).

65) Jeong, C. H.; Bode, A. M,; Pugliese, A.; Cho, Y. Y.; Kim, H. G.; Shim, J. H.; Jeon, Y. J.; Li, H.; Jiang, H.; Dong, Z. Cancer Res., 69, 5584-5591 (2009).

66) Baselga-Escudero, L.; Blade, C.; Ribas-Latre, A.; Casanova, E.; Suarez, M.; Torres, J. L.; Salvado, M. J.; Arola, L.; Arola-Arnal, A. Nucleic Acids Res., 42, 882-892 (2014). 